\title{
Economic opportunities for using sexed semen and semen of beef bulls in dairy herds
}

\author{
J. F. Ettema, ${ }^{*}{ }^{1}$ J. R. Thomasen,‡ L. Hjortø,§ M. Kargo,†§ S. Østergaard,\# and A. C. Sørensen† \\ *SimHerd A/S, Agro Business Park, Niels Pedersens Allé 2, 8830 Tjele, Denmark \\ †Department of Molecular Biology and Genetics, Center for Quantitative Genetics and Genomics, Aarhus University, Blichers Allé 20, PO Box 50, \\ 8830 Tjele, Denmark \\ ¥VikingGenetics, Ebeltoftvej 16, 8960 Randers S $\varnothing$, Assentoft, Denmark \\ §SEGES, Agro Food Park 15, 8200 Aarhus N, Denmark \\ \#Department of Animal Science, Aarhus University, Blichers Allé 20, PO Box 50, 8830 Tjele, Denmark
}

\begin{abstract}
Dairy farmers can increase the number of dairy heifer calves born in their herd by using sexed semen. They can reduce the number of both dairy bull and heifer calves by using beef semen. Long before sexed semen became commercially available, it was believed that it would provide opportunities for increasing genetic level in both herds and populations. In this study, we studied the potential for increasing the genetic level of a herd by using beef semen in combination with sexed semen. We tested the hypothesis that the potential of increasing the genetic level and the overall net return would depend on herd management. To test this hypothesis, we simulated 7 scenarios using beef semen and sexed semen in 5 herds at different management levels. We combined the results of 2 stochastic simulation models, SimHerd and ADAM. SimHerd simulated the effects of the scenarios and management levels on economic outcomes (i.e., operational return) and on technical outcomes such as the parity distribution of the dams of heifer calves, but it disregarded genetic progress. The ADAM model quantified genetic level by using the dams' parity distributions and the frequency of sexed and beef semen to estimate genetic return per year. We calculated the annual net return per slot as the sum of the operational return and the genetic return, divided by the total number of slots. Net return increased up to $€ 18$ per slot when using sexed semen in $75 \%$ genetically superior heifers and beef semen in $70 \%$ genetically inferior, multiparous cows. The assumed reliability of selection was 0.84 . These findings were for a herd with overall high management for reproductive performance, longevity, and calf survival. The same breeding strategy reduced net return by $€ 55$ per slot when
\end{abstract}

Received April 19, 2016.

Accepted January 14, 2017.

${ }^{1}$ Corresponding author: je@simherd.com management levels were average. The main reason for the large reduction in net return was the heifer shortage that arose in this scenario. Our hypothesis that the potential for beef semen to increase genetic level would be herd-specific was supported. None of the scenarios were profitable under Danish circumstances when the value of the increased genetic level was not included. A comparable improvement in genetic level could be realized by selectively selling dairy heifer calves rather than using beef semen.

Key words: sexed semen, beef semen, dairy herd, economics, genetics

\section{INTRODUCTION}

Using beef semen in dairy herds allows farmers to produce crossbred calves whose carcasses are more valuable than those of purebred calves (Wolfová et al., 2007). Furthermore, the genetic level of the herd may increase when beef semen is used in genetically inferior cows, because the offspring of these cows do not enter the milking herd. As far as we are aware, no studies have investigated the effect of using beef semen on herds' operational return (OR) and change in genetic level. When using beef semen in genetically inferior cows, the distribution of dams giving birth to dairy heifer calves would be expected to change in 2 ways. First, a smaller proportion of cows would deliver heifer calves, and these cows would be genetically superior. Second, the proportion of heifer calves born from heifers (nulliparous cows) would increase, and the proportion born form primi- and multiparous cows would decrease. The former change in distribution increases selection intensity, and the latter decreases generation interval. These different effects make it difficult to forecast change in genetic level as a result of using beef semen.

The genetic level of the herd increases when sexed semen is used on genetically superior animals (Ghavi Hossein-Zadeh et al., 2010; Ettema et al., 2011). This 
Table 1. Investigated scenarios for use of sexed semen on heifers and beef semen on multiparous cows

\begin{tabular}{lcc}
\hline Scenario $^{1}$ & $\begin{array}{c}\text { Heifers bred with } \\
\text { sexed semen }(\%)\end{array}$ & $\begin{array}{c}\text { Multiparous cows bred } \\
\text { with beef semen }(\%)\end{array}$ \\
\hline S0-B0 & 0 & 0 \\
S0-B33 & 0 & 33 \\
S25-B33 & 25 & 33 \\
S25-B60 & 25 & 60 \\
S50-B60 & 50 & 60 \\
S75-B70 & 75 & 70 \\
S75-B70Y & 75 & 70 (Y-sorted semen) \\
\hline
\end{tabular}

${ }^{1} \mathrm{~S}=$ proportion of heifers inseminated with sexed semen; $\mathrm{B}=$ proportion of cows inseminated with beef semen; $\mathrm{Y}=$ sexed beef semen (Y-chromosome enriched).

is particularly true when sexed semen is used on the youngest generations and the breeding strategy is combined with genomic testing (Hjortø et al., 2015). However, sexed semen can create a surplus of heifers in wellmanaged herds. Under the environmental restrictions of most European countries, in which milk production is limited by animal units (Denmark) or by phosphate (the Netherlands), it is undesirable to produce a high number of surplus heifers. A recommendation in these countries, where heifer calves are typically raised on the farm because there is no market for them, is to counterbalance the use of sexed dairy semen in heifers with the use of beef semen in cows to limit the size of the young stock herd.

Many simulation studies have demonstrated that management level affects the profitability of improving reproductive performance (Østergaard et al., 2005a), using sexed semen (Olynk and Wolf, 2007), changing the voluntary waiting period (Sørensen and Østergaard, 2003), making replacement decisions (De Vries, 2004), or using genomic testing (Hjortø et al., 2015). Significant between-herd differences can also be expected when estimating the economic impact of using beef semen, because it reduces the availability of replacement heifers. The need for replacement heifers differs between herds. Furthermore, the reduction in heifer calves born as a result of breeding a proportion of cows with beef semen depends on the absolute number of cows bred with beef semen and the age distribution of the herd. We expected that the profitability of using beef semen would depend on a herd's management performance in terms of reproductive performance, calf survival, and culling risk.

We hypothesized that the increase in genetic level from using beef semen in genetically inferior cows in combination with sexed semen in genetically superior heifers would be largest in herds with high management levels for reproductive performance, calf survival, and longevity. To investigate this, we simulated 7 scenarios for insemination with sexed semen on heifers and beef semen on multiparous cows and studied them at 5 herd management levels.

\section{MATERIALS AND METHODS}

\section{General Design of the Study}

We used simulation models SimHerd (Østergaard et al., 2005b) and ADAM (Pedersen et al., 2009) in this study. We used SimHerd to estimate the effect of the scenarios on technical herd effects and OR, without incorporating the effect on genetic level. We used the ADAM model to quantify genetic level in the scenarios. Hjortø et al. (2015) also used these 2 simulation models when studying the economics of genomic testing.

\section{Scenarios}

We examined and compared the effects of 7 scenarios for sexed semen and beef semen at 5 management levels. An overview of the 7 scenarios is presented in Table 1. We used beef semen on second-parity and older cows. Heifers and cows that were not bred with sexed or beef semen were bred with conventional semen from dairy bulls. An average Danish dairy farm with regard to prices, costs, production system, and management level formed the basis for the simulations (Ancker, 2011).

\section{General Framework of the Simulation Models}

SimHerd IV is a mechanistic, dynamic, and stochastic dairy herd model that simulates the production and state changes of dairy cows and young stock in a herd (Østergaard et al., 2005b). The state of an animal is defined by age, parity, lactation stage, a permanent component of milk-yield potential, actual milk yield, BW, culling status, reproductive status (estrus and pregnancy), SCC, and disease status. The prediction of the current state is made week by week for each cow and heifer in the herd. The state of each animal is updated, and the production and input consumption of the herd is calculated. In the current study, where we used the output of the SimHerd model as input for the ADAM model, it was essential that genetics not be taken into account by SimHerd, because all genetic progress was modeled in ADAM.

ADAM is a general program for stochastic simulation of selective breeding schemes in livestock (Pedersen et al., 2009). It simulates a population of animals with true breeding values, phenotypes, and EBV. In this study, we used ADAM to calculate the genetic level of the females for use of sexed semen on heifers and beef semen on multiparous cows (Table 1). 
The simulation process had 2 steps. First, we modeled the 7 scenarios for use of sexed semen and beef semen at 5 management levels using SimHerd. Then, for each management level and scenario, we used the averages across replicates of output parameters from SimHerd as input parameters in ADAM. The parameters in question were the proportion of heifer calves born from heifers bred with sexed semen, the proportion of heifer calves born from cows bred with conventional semen, and the distribution of parities of dams of purebred heifer calves. We modeled the effect of each scenario for use of sexed semen and beef semen on genetic level accordingly, using ADAM.

\section{SimHerd}

Cow Management. All parameters for AI periods, reproductive performance, and culling rates of cows and heifers were representative of an average-performing Danish dairy herd (Ancker, 2011). First-parity cows with a milk yield higher or lower than the parity-specific median were specified to have an AI period until 336 or 231 DIM, respectively. For older-parity cows, the AI periods were terminated at 315 and 210 DIM, respectively. The AI periods were initiated 49 and 42 $\mathrm{d}$ after calving (voluntary waiting period) for primiparous and multiparous cows, respectively. A cow that failed to become pregnant during the AI period was replaced when it was the lowest-yielding candidate for voluntary culling and a heifer was ready to calf and enter the herd. The proportion of cows showing estrus after calving was set at 0.95. Cows' estrus detection rate and conception rate to d 14 after AI varied between management levels.

Replacement rate was a result of individual cows' reproductive performance, disease occurrence, involuntary culling, mortality, and the availability of replacement heifers. Involuntary culling was represented with a base risk of $0.9 \%$ in wk 1 that declined linearly to $0.079 \%$ in wk 29; after that, the weekly risk was constant at $0.079 \%$ for the rest of the lactation. Mortality was represented by a constant weekly base risk of $0.034 \%$. In addition to these base risks, production diseases such as mastitis (Østergaard et al., 2005b), metabolic diseases (Østergaard et al., 2000), and lameness-causing diseases (Ettema et al., 2010) increased the cow's individual risk of involuntary culling and mortality. All parameters describing the lactation curve model in SimHerd were identical to those described by Kristensen et al. (2008).

Heifer Management. Heifers' conception rate for conventional semen was set at 0.63 , and the estrus detection rate was assumed to be 0.60 . An additional risk of fetal death, which included early fetal death, was set at 0.13 . The AI period for heifers was initiated at
$455 \mathrm{~d}$ and terminated at $606 \mathrm{~d}$. These assumptions for heifers' conception rate, estrus detection rate, and risk of fetal death meant that $90 \%$ of all heifers became pregnant during the AI period. Heifers that did not become pregnant were sold to slaughter. The proportion of heifers that became pregnant was higher for the high calf survival management level (Table 2). Heifers were sold as livestock when no cows were selected for culling and a maximum number of 202 cows was reached. Heifers were purchased when the herd size reached a minimum number of 180 cows. To realize a targeted number of 200 cow-years in the simulation, we set the maximum number of cow-years at $1 \%$ higher than the targeted number and the minimum number of cow-years at $10 \%$ lower than the targeted number. An important assumption for this study was that all female calves were raised on the farm, representative of young stock management on Danish dairy farms. Farmers' preference for a high availability of replacement heifers and the absence of a market for heifer calves justify this assumption. Whether selling some or all of the heifer calves and purchasing heifers is a better strategy was not the subject of this study.

Simulation of Sexed Semen Scenarios. We based the selection of heifers to breed with sexed semen and cows to breed with beef semen (Table 1) on randomnumber drawing, because genetics were not modeled in SimHerd. The conception rate obtained with sexed semen was set at $80 \%$ (DeJarnette et al., 2007) of that of normal semen. Heifers were bred twice with sexed semen. After 2 unsuccessful attempts with sexed semen, they were bred with conventional semen until they became pregnant or their insemination period was terminated and they were culled. In scenarios where 50 and $75 \%$ of the heifers were bred with sexed semen, we prolonged the insemination period by 7 and $14 \mathrm{~d}$, respectively. We did this to in an attempt to achieve the same proportion of pregnant heifers in each scenario. Cows selected for insemination with beef semen were bred with beef semen during the entire insemination period. Strategies for using sexed semen on heifers and beef semen on multiparous cows best represented Danish practice. All male purebred calves and all crossbred calves were sold at age $2 \mathrm{wk}$.

We simulated the scenarios described in Table 1 for 5 management levels to study between-herd differences in the scenarios' profitability. Table 2 describes the management levels. The improved management levels represented the $25 \%$ best-performing herds in terms of calf survival, longevity, and reproductive performance (Ancker, 2011). For the management level with high longevity, the risk of production diseases was reduced. The good overall management level was a combination of improved performance for all 3 parameters. 
Table 2. Parameters of the 5 management levels

\begin{tabular}{|c|c|c|c|c|c|}
\hline Management level & Average & $\begin{array}{l}\text { High calf } \\
\text { survival }\end{array}$ & $\begin{array}{l}\text { High } \\
\text { longevity }\end{array}$ & $\begin{array}{l}\text { Good reproductive } \\
\text { performance }\end{array}$ & $\begin{array}{l}\text { Good overall } \\
\text { management }\end{array}$ \\
\hline Heifer mortality risk ${ }^{1}(\%)$ & 7.5 & 2 & 7.5 & 7.5 & 2 \\
\hline Heifers pregnant ${ }^{2}(\%)$ & 90 & 95 & 90 & 90 & 95 \\
\hline Mortality base risk ${ }^{6}(\%)$ & 0.034 & 0.034 & 0.0038 & 0.034 & 0.0038 \\
\hline Conception rate ${ }^{7}$ & 0.53 & 0.53 & 0.53 & 0.57 & 0.57 \\
\hline Estrus detection rate $^{8}$ & 0.41 & 0.41 & 0.41 & 0.55 & 0.55 \\
\hline
\end{tabular}

${ }^{1}$ Overall mortality risk for a live-born heifer calf during the entire raising period (until calving). The overall mortality risk was the combined risk of a calf dying between d 1 and 14, d 15 and 63, d 64 and 182, and after d 182. The proportion of calves that died in these periods was 40 , 40,15 , and $5 \%$, respectively.

${ }^{2}$ Proportion of heifers that became pregnant during the insemination period, delivered a calf, and started the first lactation out of all surviving heifers that could become pregnant. We simulated different pregnancy rates by increasing the heifer insemination period.

${ }^{3}$ Risk in wk 1 of lactation for an average-yield, third-parity cow, without previous cases of milk fever, retained placenta, metritis, displaced abomasum, ketosis, mastitis, digital dermatitis, foul-in-the-foot, or hoof-horn diseases.

${ }^{4}$ Base risks are at a level representative for Danish dairy herds.

${ }^{5}$ Base risks of all production diseases are $50 \%$ lower than the average.

${ }^{6}$ In addition to diseases causing mortality, we included a weekly base risk for death due to other causes.

${ }^{7}$ Conception rate to d 14 after AI for healthy cows.

${ }^{8}$ Estrus detection rate for the fourth or later cycle after calving for healthy cows.

\section{ADAM}

The scenarios were applied in a single herd that did not contribute to the breeding population. The AI bulls were selected among the bulls in the breeding population and used in the herd under study. The number of AI bulls was chosen so that the annual genetic response corresponded to 0.3 standard deviation units of the breeding goal. Thus, animals that were 1 yr younger were 0.3 genetic standard deviation units better, on average. In the breeding goal for Nordic Holstein, the value of 1 genetic standard deviation unit is $€ 222$ of the true breeding goal per live-born heifer (Kargo et al., 2014). The assumed reliability was 0.84 , and the assumed average lifetime was 2.5 years when deriving economic weights. Thus, the value of 1 genetic standard deviation unit was €89 per cow-year. In all combinations of scenarios and management levels, the purchased heifers had the same genetic level as the population mean. We based selection of heifers and cows on BLUP EBV using all available phenotypic information from their own performance and their ancestors. Thus, none of the females in the herd were genotyped. The simulated breeding scheme is described in more detail in Hjort $\varnothing$ et al. (2015).

\section{Data Analysis}

In SimHerd, we simulated each scenario over 2 yr and replicated it 1,000 times. We used the simulated data from years 6 to 20 in the subsequent analyses. Initial simulation years 1 to 5 were deleted to diminish the effect of the actual state of the herd in the first simula- tion time-step. Only the results of the stable situation from SimHerd could be used as input for ADAM. Based on our experience with the model, we chose the number of replicates and monitoring period to obtain precise estimates. We calculated OR per slot as sales income minus variable costs for cows and additional young stock divided by the total number of slots (i.e., 202). We focused on economic performance per slot in this study rather than on cow-year, because the availability of heifers affects the number of cow-years in each scenario, and therefore the use of the slots in a barn. With the exception of labor associated with disease treatment, we did not include labor and management costs as variable costs.

In ADAM, each scenario covered a 25-yr period and was replicated 3,000 times. In the subsequent analyses, we used simulated data from years 16 to 25, as in Hjort $\varnothing$ et al. (2015). We calculated genetic level as the average of the true breeding values for all newborn purebred heifer calves. We used simulation years 16 to 25 because the differences in genetic level between scenarios were stable after 15 years. The breeding scheme was in full equilibrium at year 15 with regard to the Bulmer effect, generation interval, and rate of total genetic gain. Based on our experience with the model, we found a period of $10 \mathrm{yr}$ to have sufficient accuracy for estimated genetic merit. In the S0-B0 scenario, we set the genetic level at 0 and the management level at average. The genetic levels for all other scenarios are reported relative to this scenario. Differences in genetic level are presented in genetic standard deviation units. The economic value of these genetic differences, genetic return (GR), are presented in euros per slot. For all scenarios, the annual 
Table 3. Assumed prices and costs $(€)$ for the calculation of net return

\begin{tabular}{|c|c|}
\hline Assumption & Cost \\
\hline$\overline{\mathrm{ECM}^{1}(€ / \mathrm{kg})}$ & 0.35 \\
\hline TMR for cows $\left(€ /\right.$ feeding unit $\left.^{2}\right)$ & 0.19 \\
\hline Concentrates for young stock $\left(€ /\right.$ feeding unit $\left.{ }^{2}\right)$ & 0.24 \\
\hline Roughage for young stock $\left(€ /\right.$ feeding unit $\left.{ }^{2}\right)$ & 0.15 \\
\hline Conventional semen ( $€$ /dose, including service) & 24 \\
\hline Sexed semen ( €/dose, including service) & 40 \\
\hline Beef semen ( $€ /$ dose, including service) & 24 \\
\hline Purebred bull calf ( $€ / 14$-d-old calf) & 80 \\
\hline Crossbred heifer calf $(€ / 14$-d-old calf $)$ & 87 \\
\hline Crossbred bull calf $(€ / 14$-d-old calf $)$ & 178 \\
\hline Springing heifer (sale and purchase, $€$ ) & 1,275 \\
\hline Other costs per cow-year ${ }^{3}(€)$ & 230 \\
\hline Other costs per heifer-year $(€)$ & 44 \\
\hline
\end{tabular}

${ }^{1}$ Price per $\mathrm{kg}$ of ECM is based on milk with $4.20 \%$ fat and $3.4 \%$ protein.

${ }^{2}$ Feeding unit is $6.7 \mathrm{MJ}$ of $\mathrm{NE}_{\mathrm{L}}$.

${ }^{3}$ Hoof trimming, sawdust, vaccinations, registration, advisory services.

net return (NR) per slot was calculated as the sum of OR and GR.

\section{Sensitivity Analysis}

The most important price assumptions for the calculation of net return are shown in Table 3 . The prices for crossbred calves and purebred bull calves were based on the national market. A national market is established for these livestock in Denmark because 14\% of all dairy cows, at a national level, are bred with beef semen. Fattening crossbred calves makes up a substantial part of calf raisers' enterprise. In the sensitivity analysis, we evaluated the sensitivity of the premium for sexed semen, reducing the price of crossbred calves by $50 \%$, increasing the price of heifers by $20 \%$, and increasing heifer-raising costs by $€ 0.80$ per day. In terms of standard assumptions for raising costs, we included only feeding costs and other variable costs of heifer raising. Increasing heifer-raising costs by $€ 0.80$ per day represented the inclusion of the fixed costs associated with heifer raising (labor, machinery, and housing).

\section{RESULTS}

\section{Annual Net Return per Slot}

Without using sexed or beef semen (scenario S0-B0), the annual net return per slot for the different management levels were $€ 1,619 \pm 0.5$ (average), €1,632 \pm 0.7 (high calf survival), $€ 1,794 \pm 0.8$ (high longevity), $€ 1,670 \pm 0.8$ (good reproductive performance), and $€ 1,843 \pm 0.8$ (good overall management). The OR for the management levels were $€ 1,619 \pm 0.5, € 1,631 \pm$ $0.4, € 1,799 \pm 0.5, € 1,681 \pm 0.5$, and $€ 1,860 \pm 0.5$, respectively. Because the means were based on the same number of observations and due to homogeneity of the error variance, standard errors were similar and are not presented for other scenarios. Table 4 shows the differences in NR and OR between the 7 scenarios for each management level.

The difference in net return relative to scenario S0B0 was positive in all scenarios for a herd with good overall management (Table 4). For a herd with average management, the difference in NR relative to scenario S0-B0 was negative in all scenarios. Using sexed beef semen in scenario S75-B70Y resulted in an increase in NR for all management levels except average management and high longevity. However, breeding the same proportion of cows with non-sexed beef semen (S75$\mathrm{B} 70)$ resulted in a larger increase in $\mathrm{NR}$ than with S75-B70Y.

From Table 4, the GR can be calculated as NR minus OR. For scenario S0-B33, at the average management level, this means that the economic impact of the change in genetic level was $€ 4 \pm 0.6 /$ slot per year ( $-€ 64$ to $-€ 68)$. The standard errors for the estimates of GR from ADAM are of the same magnitude, due to homogeneity of the error variance. The change in OR were negative and the GR was positive in all scenarios for each management level. The S75-B70 scenario had the highest NR and GR for management levels high calf survival, good reproductive performance, and good overall management.

Table 4. Differences in annual net return ( $€$ per slot, with differences in operational return in parentheses) between scenarios at each management level

\begin{tabular}{|c|c|c|c|c|c|}
\hline Scenario $^{1}$ & Average & $\begin{array}{l}\text { High calf } \\
\text { survival }\end{array}$ & $\begin{array}{l}\text { High } \\
\text { longevity }\end{array}$ & $\begin{array}{l}\text { Good reproductive } \\
\text { performance }\end{array}$ & $\begin{array}{l}\text { Good overall } \\
\text { management }\end{array}$ \\
\hline S0-B0 & $0(0)$ & $0(0)$ & $0(0)$ & $0(0)$ & $0(0)$ \\
\hline S0-B33 & $-64(-68)$ & $-2(-8)$ & $3(-2)$ & $3(-7)$ & $3(-8)$ \\
\hline $\mathrm{S} 25-\mathrm{B} 60$ & $-147(-159)$ & $-35(-49)$ & $-62(-76)$ & $-13(-33)$ & $11(-13)$ \\
\hline S50-B60 & $-79(-93)$ & $8(-8)$ & $6(-11)$ & $10(-13)$ & $16(-10)$ \\
\hline S75-B70 & $-55(-71)$ & $10(-7)$ & $9(-10)$ & $12(-13)$ & $18(-12)$ \\
\hline
\end{tabular}

${ }^{1} \mathrm{~S}=$ proportion of heifers inseminated with sexed semen; $\mathrm{B}=$ proportion of cows inseminated with beef semen; $\mathrm{Y}=$ sexed beef semen (Y-chromosome enriched). 
Table 5. Differences in genetic level (genetic standard deviation units of the breeding goal, with interactions in parentheses) between scenarios at each management level ${ }^{1}$

\begin{tabular}{|c|c|c|c|c|c|}
\hline Scenario $^{2}$ & Average & $\begin{array}{l}\text { High calf } \\
\text { survival }\end{array}$ & $\begin{array}{l}\text { High } \\
\text { longevity }\end{array}$ & $\begin{array}{l}\text { Good reproductive } \\
\text { performance }\end{array}$ & $\begin{array}{l}\text { Good overall } \\
\text { management }\end{array}$ \\
\hline S0-B0 & 0 & 0.013 & -0.052 & -0.119 & -0.187 \\
\hline S0-B33 & 0.037 & $0.076(0.026)$ & $0.011(0.026)$ & $-0.013(0.069)$ & $-0.065(0.085)$ \\
\hline $\mathrm{S} 25-\mathrm{B} 33$ & 0.101 & $0.139(0.025)$ & $0.070(0.021)$ & $0.022(0.040)$ & $-0.019(0.068)$ \\
\hline $\mathrm{S} 25-\mathrm{B} 60$ & 0.140 & $0.164(0.011)$ & $0.114(0.027)$ & $0.101(0.080)$ & $0.081(0.129)$ \\
\hline $\mathrm{S} 50-\mathrm{B} 60$ & 0.169 & $0.193(0.012)$ & $0.147(0.030)$ & $0.143(0.093)$ & $0.105(0.124)$ \\
\hline S75-B70 & 0.185 & $0.212(0.014)$ & $0.169(0.036)$ & $0.166(0.100)$ & $0.148(0.150)$ \\
\hline S75-B70Y & 0.183 & $0.214(0.018)$ & $0.183(0.052)$ & $0.174(0.109)$ & $0.157(0.162)$ \\
\hline
\end{tabular}

${ }^{1}$ The reference scenario was the breeding scenario with no sexed or beef semen and average management. Interactions were calculated as the difference in genetic level as a result of combining the scenarios and management levels, compared with the main effects of the scenarios and management levels.

${ }^{2} \mathrm{~S}=$ proportion of heifers inseminated with sexed semen; $\mathrm{B}=$ proportion of cows inseminated with beef semen; $\mathrm{Y}=$ sexed beef semen (Y-chromosome enriched).

\section{Genetic Level}

Table 5 shows the differences in genetic level (genetic standard deviation units of the breeding goal) between the scenarios. In S0-B0, the difference in genetic level was positive between average management and management with high calf survival, and it was negative between the 3 other improved management levels and average management. We calculated interactions as the difference in genetic level from combining the scenarios and management levels compared with the main effects of the scenarios and management levels. Good overall management had the lowest genetic level and the highest interaction terms for each scenario. The genetic level in S0-B0 was highest for the management level with high calf survival compared with the other management levels, but the interaction term was lowest when sexed semen was used on $75 \%$ of heifers and beef semen on $70 \%$ of cows.

Tables 6 to 9 provide an overview of technical values for the various scenarios. The number of cow-years per 100 slots remained unchanged in all scenarios for good overall management (Table 6). For average management, the number of cow-years was reduced by up to 6 per 100 slots. For S25-B60 with average management, the surplus of 2 heifers per 100 slots changed by -4 , meaning that 2 heifers were purchased in this scenario (Table 6). The S25-B60 scenario also led to a reduction in number of cow-years for herds with higher management levels for calf survival, longevity, and reproductive performance.

In S25-B60 with good overall management, 33 crossbred calves were born each year, and the number of heifer-years was reduced by $30 \%$ compared with S0-B0 (Table 7). This reduction in young stock did not result in a reduction in cow-years (Table 6). The number of heifer-years was reduced by only $26 \%$ in S50-B60 for average management, but this reduction in young stock resulted in 3 fewer cow-years (Table 6).

The number of calvings per year (Table 8) and replacement rate (Table 9) were reduced in all scenarios at all management levels. Age at first calving increased in all scenarios (Table 9).

Table 8 shows that milk production per slot decreased in all scenarios compared with S0-B0, except for S25-B60 with good overall management. Changes in milk production were minor for the aforementioned management level, but we found large decreases in milk

Table 6. Absolute number of cow-years and surplus heifers (in parentheses) per 100 slots for simulation yr 6 to 20 in S0-B0, and differences in the number of cow-years and change in surplus heifers for other scenarios compared with S0-B0 within each management level

\begin{tabular}{|c|c|c|c|c|c|}
\hline Scenario $^{1}$ & Average & $\begin{array}{l}\text { High calf } \\
\text { survival }\end{array}$ & $\begin{array}{l}\text { High } \\
\text { longevity }\end{array}$ & $\begin{array}{l}\text { Good reproductive } \\
\text { performance }\end{array}$ & $\begin{array}{l}\text { Good overall } \\
\text { management }\end{array}$ \\
\hline S0-B0 & $99(2)$ & $99(6)$ & $99(5)$ & $99(9)$ & $99(17)$ \\
\hline S25-B60 & $-6(-4)$ & $-1(-6)$ & $-2(-5)$ & $-1(-9)$ & $0(-12)$ \\
\hline S50-B60 & $-3(-2)$ & $0(-5)$ & $0(-4)$ & $0(-7)$ & $0(-9)$ \\
\hline S75-B70 & $-2(-2)$ & $0(-4)$ & $0(-4)$ & $0(-7)$ & $0(-9)$ \\
\hline
\end{tabular}

${ }^{1} \mathrm{~S}=$ proportion of heifers inseminated with sexed semen; $\mathrm{B}=$ proportion of cows inseminated with beef semen; $\mathrm{Y}=$ sexed beef semen (Y-chromosome enriched). 
Table 7. Absolute number of heifer-years and live-born crossbred calves (in parentheses) per 100 slots for simulation yr 6 to 20 in S0-B0, and differences in the number of heifer-years and live-born crossbred calves for other scenarios compared with S0-B0 within each management level

\begin{tabular}{|c|c|c|c|c|c|}
\hline Scenario $^{1}$ & Average & $\begin{array}{l}\text { High calf } \\
\text { survival }\end{array}$ & $\begin{array}{c}\text { High } \\
\text { longevity }\end{array}$ & $\begin{array}{l}\text { Good reproductive } \\
\text { performance }\end{array}$ & $\begin{array}{l}\text { Good overall } \\
\text { management }\end{array}$ \\
\hline $\begin{array}{l}\text { S0-B0 } \\
\text { S0-B33 } \\
\text { S25-B33 } \\
\text { S25-B60 } \\
\text { S50-B60 } \\
\text { S75-B70 } \\
\text { S75-B70Y }\end{array}$ & $\begin{array}{r}96(0) \\
-22(11) \\
-11(11) \\
-33(20) \\
-25(21) \\
-22(25) \\
-22(23)\end{array}$ & $\begin{array}{r}106(0) \\
-16(12) \\
-7(12) \\
-30(22) \\
-17(23) \\
-15(28) \\
-14(26)\end{array}$ & $\begin{array}{r}97(0) \\
-17(13) \\
-10(13) \\
-33(24) \\
-22(26) \\
-21(31) \\
-20(29)\end{array}$ & $\begin{array}{r}99(0) \\
-17(16) \\
-11(16) \\
-31(30) \\
-23(30) \\
-24(36) \\
-23(34)\end{array}$ & $\begin{array}{l}105(0) \\
-18(17) \\
-14(17) \\
-32(33) \\
-26(33) \\
-29(39) \\
-26(37)\end{array}$ \\
\hline
\end{tabular}

${ }^{1} \mathrm{~S}=$ proportion of heifers inseminated with sexed semen; $\mathrm{B}=$ proportion of cows inseminated with beef semen; $\mathrm{Y}=$ sexed beef semen (Y-chromosome enriched).

yield with average management. The changes in milk yield per cow-year as a consequence of improving the cows' genetic level are not included in Table 8. Those results represent milk yield per slot, as simulated by SimHerd, disregarding genetic progress. Milk yield, like fertility, longevity, and udder health, is a breeding goal trait (Kargo et al., 2014). Increases in genetic standard deviation of the breeding goal were estimated by ADAM (Table 5).

\section{Sensitivity Analysis}

A bar diagram showing sensitivity for prices and costs is presented in Figure 1 for good overall management. The "Standard price assumptions" bars show the results when using the prices and costs presented in Table 3. The results for these bars correspond to those in Table 4. The "Price heifers +20\%" bars show the economic results of the scenarios when the price for buying and selling springing heifers was increased by $20 \%$ from $€ 1,275$ to $€ 1,530$, leaving all other prices, costs, and assumptions unchanged. The economic performance of all beef semen scenarios was negative compared with S0-B0 when the value of heifers was increased. This was because S0-B0 benefits particularly from the increase in value: 17 heifers were sold in this scenario. The reduction in economic return was largest in S75-B70Y, in which sexed beef semen was used (from $€ 5$ to $-€ 24$ per slot) when the price of crossbred calves was halved. The premium for sexed semen was €16 per dose. When using the same price for sexed semen as for conventional semen ( $€ 24$ per dose), the simulated increases in net return were larger in all but S0-B33. The price sensitivity was most profound in S75-B70Y, as $\mathrm{NR}$ increased from $€ 5$ per slot to $€ 29$. With the same price for sexed semen, S75-B70Y outperformed S75-B70, in which no sexed beef semen was used; net return only increased from €18 to €23 in the latter scenario when we assumed that sexed semen had the same price as normal semen. However, the results were most sensitive to assumed heifer-raising costs. When using standard price assumptions, feeding costs and other variable costs of heifer raising amounted to $€ 1.12$ per feeding day in S0-B0. Increasing costs by $€ 0.80$ per day represented the inclusion of fixed costs associated with heifer raising. With an age at first calving of 792 d (Table 9) in the default scenario, the costs of raising a heifer amount to $€ 887$ and $€ 1,521$, when including variable costs and all costs, respectively. The sensitivity to heifer-raising costs was most profound in S25-B60: net return increased by $€ 94$ per slot (from $€ 11$ to $€ 105$ ) when heifer-raising costs increased by $€ 0.80$ per day.

Table 8. Absolute number of calvings per 100 slots and milk yield in kilograms of ECM per slot (in parentheses) are presented for simulation yr 6 to 20 in S0-B0, and differences in the number of calvings and milk yield for other scenarios compared with S0-B0 within each management level

\begin{tabular}{|c|c|c|c|c|c|}
\hline Scenario $^{1}$ & Average & $\begin{array}{l}\text { High calf } \\
\text { survival }\end{array}$ & $\begin{array}{l}\text { High } \\
\text { longevity }\end{array}$ & $\begin{array}{l}\text { Good reproductive } \\
\text { performance }\end{array}$ & $\begin{array}{l}\text { Good overall } \\
\text { management }\end{array}$ \\
\hline $\begin{array}{l}\text { S0-B0 } \\
\text { S0-B33 } \\
\text { S25-B33 } \\
\text { S25-B60 } \\
\text { S50-B60 } \\
\text { S75-B70 } \\
\text { S75-B70Y }\end{array}$ & $\begin{array}{r}107(9,461) \\
-14(-440) \\
-6(-130) \\
-21(-938) \\
-16(-577) \\
-14(-452) \\
-15(-521)\end{array}$ & $\begin{aligned} 110 & (9,498) \\
-4 & (-59) \\
-1 & (-24) \\
-14 & (-329) \\
-5 & (-62) \\
-4 & (-51) \\
-5 & (-34)\end{aligned}$ & $\begin{aligned} 107 & (9,809) \\
-5 & (-44) \\
-2 & (-14) \\
-16 & (-457) \\
-7 & (-104) \\
-7 & (-95) \\
-8 & (-111)\end{aligned}$ & $\begin{array}{l}111(9,538) \\
-2(-28) \\
-1(-15) \\
-8(-189) \\
-4(-64) \\
-4(-68) \\
-4(-63)\end{array}$ & $\begin{array}{l}109(9,854) \\
-1(-9) \\
-1(3) \\
-2(-22) \\
-2(-12) \\
-2(-17) \\
-2(-16)\end{array}$ \\
\hline
\end{tabular}

${ }^{1} \mathrm{~S}=$ proportion of heifers inseminated with sexed semen; $\mathrm{B}=$ proportion of cows inseminated with beef semen; $\mathrm{Y}=$ sexed beef semen (Y-chromosome enriched). 
Table 9. Replacement rate and age at first calving in days (in parentheses) for simulation yr 6 to 20 in S0-B0, and differences in replacement rate for other scenarios compared with S0-B0 within each management level

\begin{tabular}{|c|c|c|c|c|c|}
\hline Scenario $^{1}$ & Average & $\begin{array}{l}\text { High calf } \\
\text { survival }\end{array}$ & $\begin{array}{c}\text { High } \\
\text { longevity }\end{array}$ & $\begin{array}{l}\text { Good reproductive } \\
\text { performance }\end{array}$ & $\begin{array}{l}\text { Good overall } \\
\text { management }\end{array}$ \\
\hline $\begin{array}{l}\text { S0-B0 } \\
\text { S0-B33 } \\
\text { S25-B33 } \\
\text { S25-B60 } \\
\text { S50-B60 } \\
\text { S75-B70 } \\
\text { S75-B70Y }\end{array}$ & $\begin{array}{l}40(788) \\
-6(1) \\
-3(2) \\
-7(7) \\
-7(5) \\
-6(8) \\
-6(8)\end{array}$ & $\begin{array}{l}42(794) \\
-3(1) \\
-1(2) \\
-7(3) \\
-3(4) \\
-2(6) \\
-2(6)\end{array}$ & $\begin{array}{l}36(788) \\
-3(1) \\
-2(2) \\
-8(3) \\
-5(5) \\
-4(7) \\
-4(7)\end{array}$ & $\begin{array}{l}33(787) \\
-1(1) \\
-1(2) \\
-4(3) \\
-3(5) \\
-3(8) \\
-2(8)\end{array}$ & $\begin{array}{l}30(792) \\
-1(1) \\
-1(2) \\
-2(3) \\
-2(5) \\
-2(7) \\
-1(7)\end{array}$ \\
\hline
\end{tabular}

${ }^{1} \mathrm{~S}=$ proportion of heifers inseminated with sexed semen; $\mathrm{B}=$ proportion of cows inseminated with beef semen; $\mathrm{Y}=$ sexed beef semen (Y-chromosome enriched).

Assuming higher heifer-raising costs made S25-B60 the most profitable scenario; it was the third most profitable scenario using standard price assumptions.

\section{DISCUSSION}

This study demonstrated that the use of beef semen in genetically inferior cows increased the genetic level of the herd. This increase can be explained by the fact that inferior cows do not contribute offspring to the next generation of dairy cows. The increase in genetic level was most profound when beef semen was used in genetically inferior animals and heifers were bred with sexed semen. Using beef semen alone (S0-B33) increased the genetic level by 0.122 , and combining beef semen with sexed semen (S75-B70) increased the genetic level

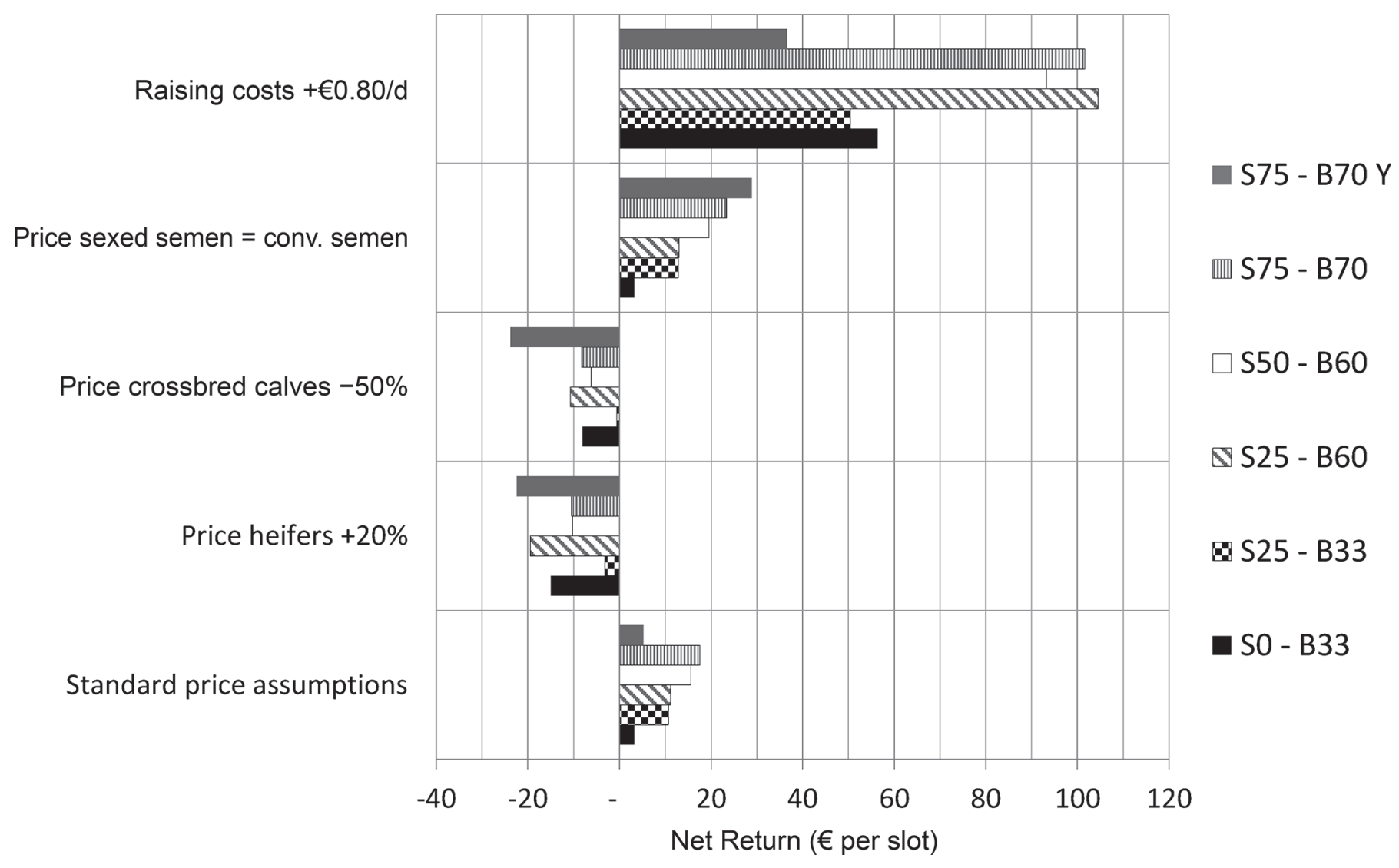

Figure 1. Difference in annual net return ( $€$ per slot) between 6 scenarios and the scenario in which no sexed or beef semen is used (S0-B0). Differences are shown for prices and costs and for management level with good overall management. The 6 scenarios represent strategies for the use of sexed semen and beef semen. $\mathrm{S}=$ proportion of heifers inseminated with sexed semen; $\mathrm{B}=$ proportion of cows inseminated with beef semen; $\mathrm{Y}=$ sexed beef semen (Y-chromosome enriched). 
by 0.335 in a herd that had good overall management. This study supported our hypothesis that genetic level increases most when combined with high management levels; in the S75-B70 scenario, the increase in genetic level varied from 0.185 to 0.335 depending on the management level. Sexed semen also improved genetic level in other studies (Weigel, 2004; Ghavi Hossein-Zadeh et al., 2010). The effect on net profit estimated in the bioeconomic model of Ghavi Hossein-Zadeh et al. (2010) was generally negative for herds with a fixed size. McCullock et al. (2013) focused on estimating the economic opportunities of using beef semen in combination with sexed semen, where genetic gain with sexed semen was incorporated. The authors found that this scenario was rarely profitable when compared to scenarios in which only conventional semen or sexed semen was used.

\section{Effects of Management Levels and Scenarios}

High calf survival and good overall management had the highest and lowest genetic levels in the S0-B0 scenario, respectively. The replacement rates in Table 9 , explain the ranking of the different management levels by genetic level; a high replacement rate resulted in a shorter generation interval, and therefore a higher genetic level.

The OR was negatively affected by using beef semen in all scenarios and at each management level. This means that producing crossbred calves is not lucrative when operational expenses and the costs of raising and selling springing heifers versus selling crossbred calves is taken into consideration. In other words, using beef semen is not profitable under Danish conditions and when GR is not included in the calculation. When adding the GR to the OR, the resulting NR was positive in all scenarios for overall good management. This can be explained by the fact that the number of cow-years did not drop in any scenario (Table 6). Calf survival, reproductive performance, and cow longevity were all sufficiently high, enabling this management level to reduce the numbers of young stock by up to $30 \%$ in the S25-B60 scenario, where beef semen was used most intensively. It should be noted that the low replacement rate was a result of good herd health and reproductive performance, but also of the decision parameters for AI period. In the herd with good overall management, using a shorter AI period to obtain a replacement rate of 40 instead of 30 would have resulted in an increase in GR but also a decrease in OR.

Milk yield per slot was reduced in most scenarios compared with S0-B0 at each management level (Table 8 ). This was due to the lower availability of replacement heifers, resulting in a lower replacement rate and a lower number of calvings. This reduction in replace- ment rate did not reflect an increase in the number of lactations per cow: simply that the replacement of candidates for voluntary culling was postponed. The voluntary culling candidates stayed longer in the herd before they were culled. The benefit of having older cows was counterbalanced by having fewer calvings and more late-lactating cows, resulting in a lower milk yield per slot in all scenarios.

Reduction in Number of Cow-Years. For the high calf survival management level, S25-B60 resulted in 14 fewer calvings, 30 fewer heifer-years, and 1 fewer cow-year per 100 slots. The fact that the simulated herd could not maintain a stable size indicated that it was not sufficiently self-recruiting. The demand for replacement heifers was higher than the number of heifers produced in the herd. The lower heifer availability also resulted in a decrease in milk yield per slot of 329 $\mathrm{kg}$ of ECM. Mainly due to the reduction in cow-years, the OR at the herd level decreased by $€ 49$ per slot. An important assumption behind the reduction in cowyears was the threshold of 180 for purchasing heifers, meaning that the model did not start purchasing heifers until the number of cows dropped below 180. If this threshold had been higher, the herd would have purchased more heifers, but that would have resulted in a smaller reduction in the number of cow-years. Experience with the model has shown that increasing the minimum number of cows results in a smaller reduction in OR in this scenario.

Selling of Heifers. The model compared selling surplus heifers in the S0-B0 scenario with the use of sexed and beef semen in the other scenarios. Surplus heifers were sold when no cows were on the culling list. Therefore, the selling of heifers was done at random. It can be argued that selling heifers randomly instead of selectively underestimates the genetic level in S0-B0, in which 2 to 17 heifers per 100 slots were sold annually, depending on the management level (Table 6). However, the heifers sold in these scenarios were sold in the week of their expected calving date, and were therefore available to replace cows before they were sold. They were only sold when no cows were on the culling list, making the sale timing random. An interesting scenario would have been to study the potential mentioned by Hohenboken (1999) and reported by Weigel et al. (2012) of selling heifers selectively, in the early stage of pregnancy or as calves. However, if we had simulated this, the heifers sold would not have been available to replace cows on the culling list. This strategy would have resulted in delayed culling of low-yielding cows and reduced the OR in this scenario compared with selling heifers in the week of their expected calving. Furthermore, changes in genetic level as a result of selling heifers selectively depends on whether the selection 
of heifers is made based on EBV or genomic testing (Calus et al., 2015).

\section{Interactions Between Management Levels and Scenario}

We expected that the economic impact of using beef semen and sexed semen would depend on management level in the herd. This was first demonstrated by the fact that all scenarios were profitable at the good overall management level, and no scenario was were profitable at the average management level (Table 4). As well, we found interactions, nearly all of which were positive (Table 5 ). In S0-B0, the herds with good overall management and average management differed widely in terms of genetic level $(-0.187$ and 0 genetic standard deviation units, respectively). In S75-B70, the genetic level increased by 0.345 for good overall management and by only 0.183 for average management. There are 2 reasons for this. First of all, the number of calvings - and therefore the number of younger, genetically superior heifers entering the herd - dropped by 14 per 100 slots for average management and by only 2 for good overall management. Second, the replacement rate was lower with good overall management (30\%) than with average management (40\%), meaning that the proportion of older cows was largest for good overall management. Using beef semen intensively on older cows resulted in a stronger response when more older cows were in the herd.

\section{Sensitivity Analysis}

Increasing the price of heifers resulted in an increase in net return in S0-B0, rather than a decrease in net return in the beef semen scenarios. As a result, the difference in net return between the beef semen scenarios and S0-B0 decreased. Reducing the price for both crossbred bull calves and heifer calves by $50 \%$ had a similar effect, compared with increasing the price of heifers by $20 \%$. The sensitivity analysis illustrated that changes in calf and heifer prices were of minor importance, compared with changes in the assumed costs of heifer raising. Raising costs were increased by $€ 0.80$ per day to include all fixed costs that were not included in the calculation of the OR (housing, labor and other fixed costs). These assumed costs should be considered by producers, despite the fact that they are not expenses and do not affect the farm's OR. Sensitivity to heiferraising costs was most profound in S25-B60. This was not due to the use of sexed semen and the increased age at first calving in this scenario, but instead due to a large reduction in the number of heifers compared with S0-B0. We have presented the sensitivity analysis only for good overall management. Presenting the sensitivity analyses for other management levels was not considered relevant for scenarios in which the number of cow-years was reduced. Danish dairy farmers will typically avoid implementing an insemination strategy that means a herd cannot be sufficiently self-recruiting. Purchasing heifers is typically avoided, primarily for bio-security reasons. Furthermore, the sensitivity analyses for the other management levels showed the same pattern as the analysis for good overall management.

\section{Environmental Impact}

The number of heifer-years was reduced from 105 per 100 slots in S0-B0 to $73(-32)$ in S25-B60. This reduction led to the potential to increase the number of cow-years by 8.5 , within the same number of methaneproducing equivalents, according to the Danish system for environmental regulation (Danish Ministry of Agriculture, 2002), which limits farm operations according to these parameters. With 8.5 extra cow-years, the annual OR increases proportionally by $8.5 \%$ (i.e., by $€ 15,810$ at the herd level8.5 cow-years $\times € 1,860$ per slot). Using the assumption from Danish budgeting programs of $€ 604$ per cow-year for investing in slots for the extra cows and extra fixed costs such as labor, water, and electricity, the total fixed costs would increase annually by $€ 5,134$. Reducing the increase in OR with the extra fixed costs, the potential increase in annual profit would be $€ 10,676$ for a 100 -cow herd. The word "potential" should be stressed, because increasing cow-number is not possible in every production system (milking robots). Furthermore, a comparable reduction in animal units can be realized by selling dairy calves at an early age, as suggested by Hohenboken (1999).

\section{CONCLUSIONS}

Given the present economic circumstances and prices, an average-performing Danish dairy herd cannot benefit from the beef semen scenarios designed in this study, because the demand for heifers is too high. In herds with above-average management levels for calf survival, longevity, and reproductive performance, economic performance can be improved by combining the use of sexed and beef semen. Economic performance improved only when including the effect of the changes in genetic level and was most sensitive to the heiferraising costs used in the calculations. We found a positive interaction between using beef semen and sexed dairy semen and improving management levels with low replacement rates. Within management levels, the best economic strategy changed depending on whether improvement in genetic level was considered or not. 
Decision-support models should able to estimate the effect of different breeding strategies on both operational return and genetic level; otherwise, milk producers may make suboptimal decisions.

\section{ACKNOWLEDGMENTS}

The research leading to these results received funding from the European Union Seventh Framework Programmes (FP7:2007-2013) under grant agreement no. 311776. The authors thank 2 anonymous referees for their valuable suggestions on a previous version of this paper.

\section{REFERENCES}

Ancker, S. 2011. ReproManagement-sund fornuft, Kapitel 1. Accessed Oct. 11, 2016. https://www.landbrugsinfo.dk/Kvaeg/ Reproduktion/Sider/Startside.aspx. [In Danish]

Calus, M. P. L., P. Bijma, and R. F. Veerkamp. 2015. Evaluation of genomic selection for replacement strategies using selection index theory. J. Dairy Sci. 98:6499-6509.

Danish Ministry of Agriculture. 2002. Plant directorate. Note on calculation of animal units. Accessed Feb. 2, 2017. http://www. statensnet.dk/pligtarkiv/fremvis.pl?vaerkid $=16582 \&$ reprid $=0 \&$ fili $\mathrm{d}=34$ \&iarkiv $=1$

De Vries, A. 2004. Economics of delayed replacement when cow performance is seasonal. J. Dairy Sci. 87:2947-2958.

DeJarnette, J. M., R. L. Nebel, J. Meek, J. Wells, and C. E. Marshall. 2007. Commercial application of sex-sorted semen in Holstein heifers. J. Dairy Sci. 90(Suppl. 1):228. (Abstr.)

Ettema, J., S. Østergaard, and A. R. Kristensen. 2010. Modelling the economic impact of three lameness causing diseases using herd and cow level evidence. Prev. Vet. Med. 95:64-73.

Ettema, J. F., S. Østergaard, and M. K. Sørensen. 2011. Effect of including milk yield on evaluating the use of sexed semen and other reproduction strategies in a dairy herd. Animal 5:1887-1897.

Ghavi Hossein-Zadeh, N., A. Nejati-Javaremi, S. R. Miraei-Ashtiani, and H. Kohram. 2010. Biol.-economic evaluation of the use of sexed semen at different conception rates and herd sizes in Holstein populations. Anim. Reprod. Sci. 121:17-23.
Hjortø, L., J. F. Ettema, M. Kargo, and A. C. Sørensen. 2015. Genomic testing interacts with reproductive surplus in reducing genetic lag and increasing economic net return. J. Dairy Sci. 98:646-658.

Hohenboken, W. D. 1999. Applications of sexed semen in cattle production. Theriogenology 52:1421-1433.

Kargo, M., L. Hjort $\varnothing$, M. Toivonen, J. A. Eriksson, G. P. Aamand, and J. Pedersen. 2014. Economic basis for the Nordic Total Merit Index. J. Dairy Sci. 97:7879-7888.

Kristensen, E., S. Østergaard, M. A. Krogh, and C. Enevoldsen. 2008 Technical indicators of financial performance in the dairy herd. J. Dairy Sci. 91:620-631.

McCullock, K., D. L. K. Hoag, J. Parsons, M. Lacy, G. E. Seidel Jr., and W. Wailes. 2013. Factors affecting economics of using sexed semen in dairy cattle. J. Dairy Sci. 96:6366-6377.

Olynk, N. J., and C. A. Wolf. 2007. Expected net present value of pure and mixed sexed semen artificial insemination strategies in dairy heifers. J. Dairy Sci. 90:2569-2576.

Østergaard, S., M. G. G. Chagunda, N. C. Friggens, T. W. Bennedsgaard, and I. C. Klaas. 2005b. A stochastic model simulating pathogen-specific mastitis control in a dairy herd. J. Dairy Sci. 88:4243-4257.

Østergaard, S., N. C. Friggens, and M. G. G. Chagunda. 2005a. Technical and economic effects of an inline progesterone indicator in a dairy herd estimated by stochastic simulation. Theriogenology 64:819-843.

Østergaard, S., J. T. Sørensen, and A. R. Kristensen. 2000. A stochastic model simulating the feeding-health-production complex in a dairy herd. J. Dairy Sci. 83:721-733.

Pedersen, L. D., A. C. Sørensen, M. Henryon, S. Ansari-Mahyari, and P. Berg. 2009. ADAM: A computer program to simulate selective breeding schemes for animals. Livest. Sci. 121:343-344.

Sørensen, J. T., and S. Østergaard. 2003. Economic consequences of postponed first insemination of cows in a dairy cattle herd. Livest. Prod. Sci. 79:145-153.

Weigel, K. A., P. Hoffman, W. Herring, and T. Lawlor Jr.. 2012. Potential gains in lifetime net merit from genomic testing of cows, heifers, and calves on commercial dairy farms. J. Dairy Sci. 95:2215-2225.

Weigel, K. A. 2004. Exploring the role of sexed semen in dairy production systems. J. Dairy Sci. 87(E. Suppl.):E120-E130.

Wolfová, M., J. Wolf, J. Kvapilík, and J. Kica. 2007. Selection for profit in cattle: II. Economic weights for dairy and beef sires in crossbreeding systems. J. Dairy Sci. 90:2456-2467. 